\title{
Proteolytic activity in stored aerobic granular sludge and structural integrity
}

\author{
Sunil S. Adav ${ }^{\text {a }}$, Duu-Jong Lee ${ }^{\mathrm{a}, *}$, Juin-Yih Lai ${ }^{\mathrm{b}}$ \\ a Department of Chemical Engineering, National Taiwan University, Taipei 10617, Taiwan \\ ${ }^{\mathrm{b}}$ Department of Chemical Engineering, RE'D Center of Membrane Technology, Chung Yuan Christian University, Chungli 32023, Taiwan
}

\section{A R T I C L E I N F O}

\section{Article history:}

Received 13 April 2008

Received in revised form 24 May 2008

Accepted 27 May 2008

Available online 9 July 2008

\section{Keywords:}

Aerobic granules

Protease

Proteolytic bacteria

EPS

\begin{abstract}
A B S T R A C T
Aerobic granules lose stability during storage. The goal of this work was to highlight the main cause of stability loss for stored granules as intracellular protein hydrolysis. The quantity of extracellular proteins was noted to be significantly lower during granule storage, and protease enzyme activities were correspondingly higher in the cores of stored granules. The proteolytic bacteria, which secrete highly active protease enzymes, were for the first time isolated and characterized by analyzing 165 rDNA sequences. The proteolytic bacteria belonged to the genera Pseudomonas, Raoultella, Acinetobacter, Pandoraea, Klebsiella, Bacillus and uncultured bacterium, and were grouped into Proteobacteria, Enterobacteria and Firmicutes. The PB1 (Pseudomonas aeruginosa) strain, which exhibited very high proteolytic activity during the skim milk agar test, was located at the core regime with active protease enzymes, and was close to the obligate anaerobic strain Bacteroides sp. Hence, the extracellular proteins in stored granules were proposed to be hydrolyzed by enzymes secreted by proteolytic bacteria with the hydrolyzed products ultimately being used by nearby anaerobic strains. This process gradually digests the protein core, and eventually consumes the entire granule.
\end{abstract}

(c) 2008 Elsevier Ltd. All rights reserved.

\section{Introduction}

Aerobic sludge granulation is a novel wastewater treatment technology that decontaminates high-strength wastewater at an acceptable rate (Beun et al., 1999; Peng et al., 1999). The aerobic granules produced have a dense and strong structure, good settleability, high biomass retention, and high tolerance to medium toxicity (Tay et al., 2001a; Su and Yu, 2005). Aerobic granules have been cultivated in a sequential biological reactor (Tay et al., 2001b; Liu and Tay, 2008; Yang et al., 2004; Wang et al., 2007). Unfortunately when stored under idle conditions, aerobic granules lose stability and activity (Zhang et al., 2005). Liu and Tay (2008) revealed that short starvation time yielded unstable granules.

Tay et al. (2002a) determined that after four months of storage at $4{ }^{\circ} \mathrm{C}$ in nutritional solution, initial metabolic activity of glucosefed and acetate-fed granules was reduced by $60 \%$ and $90 \%$, respectively. Liu et al. (2004a) indicated that after eight weeks of storage at $4{ }^{\circ} \mathrm{C}$ in tap water and in a physiological solution, granule sizes decreased by $33.6 \%$ and $22.4 \%$, respectively. Zhu and Wilderer (2003) showed that glucose-fed aerobic granules did not significantly change in size, color, or settleability after storage for seven weeks at room temperature. Liu et al. (2005) recovered the microbial activity of aerobic granules stored for four months after two days in a pilot-scale aerobic granular sludge reactor. Zeng et al.

\footnotetext{
* Corresponding author. Tel.: +886 2 23625632; fax: +886223623040.

E-mail address: djlee@ntu.edu.tw (D.-J. Lee).
}

(2007) determined that their phthalic acid-degrading aerobic granules, after storage at $4{ }^{\circ} \mathrm{C}$ for eight weeks, had fully restored organic carbon removal efficiency and adenosine triphosphate content. Wang et al. (2006) observed that aerobic granules deprived of carbon, nitrogen, and phosphorus exhibited reduced extracellular polymeric substances (EPSs) content, low microbial activity, and poor settleability. Adav et al. (2007a,b) assessed the stability and activity of phenol-fed, aerobic granules following 90 and 180 days of storage in six different media at room temperature, $4{ }^{\circ} \mathrm{C}$ and $-20^{\circ} \mathrm{C}$. Granules lost stability and activity after prolonged storage under anaerobic conditions. Particularly, granules reactivated when stored at $-20^{\circ} \mathrm{C}$ for up to 180 days, except for those stored in Milli-Q water, and had $82-99 \%$ of the phenol degradation capacity of fresh granules. Zhu (2004) determined that granules remained stable even after storage for two years in tap water at an ambient temperature $\left(16-26^{\circ} \mathrm{C}\right)$. This is not easily attained in practice as cell hydrolysis of granules always occurs at room temperature.

Aerobic granules are enriched with proteins compared with conventional activated sludge flocs that are not (Liu et al., 2004b; Adav et al., 2007a,b. Extracellular enzymes can hydrolyze proteins and carbohydrates in sludge flocs (Frolund et al., 1995; Nielsen et al., 1996; Cadoret et al., 2002; Yu et al., 2008). Moreover, starvation can cause cells to degrade secreted EPS into food (Patel and Gerson, 1974; Boyd and Chakrabarty, 1994; Zhang et al., 1999; Ruijssenaars et al., 2000; Zhang and Bishop, 2003). Wang et al. (2007) noted that aerobic granules can degrade roughly $50 \%$ of secreted EPS 
when no other carbon source was available. Zhang et al. (2007) determined that extracellular protein is involved in maintaining aerobic granule stability. Adav et al. (2007a) noted that large vacuoles existed in stored granules prior to breakdown. These authors and Tay et al. (2002b) identified the obligate anaerobic strain Bacteroides sp. and anaerobic metabolites (acetate and $\mathrm{NH}_{3}-\mathrm{N}$ ) in stored granules and, hence, hypothesized that anaerobic degradation of proteins in granule core was likely correlated with stability loss of stored granules. Yu and co-workers ( $\mathrm{Ni}$ and $\mathrm{Yu}, 2008$; Ni et al., 2008) noted based on mathematical model that denitrifiers could present in the aerobic granules. However, neither enzymes nor strains were isolated from aerobic granules corresponding to the hypothesized "internal core hydrolysis" concept to the granule integrity.

This present work explored the principle mechanisms corresponding to loss of granule stability during storage. The organisms and their respective proteolytic activities of the proteases therein were for the first time identified. These findings confirmed the "internal core hydrolysis" hypothesis for stability loss of stored granules.

\section{Methods}

\subsection{Granule samples}

Aerobic granules were cultivated with the procedures described by Adav et al. (2007b). Stable granules formed in three weeks. The cultivated, mature granules (named original granules) were washed with pure water and then stored at $8{ }^{\circ} \mathrm{C}$ for 60 days in reagent bottles containing synthetic wastewater with compositions the same as those used by Adav et al. (2007a,b) combined with $250 \mathrm{mg} \mathrm{l}^{-1}$ phenol and $400 \mathrm{mg} \mathrm{l}^{-1}$ peptone. Prior to and following storage, granules were sampled and extracted for EPS and the associated proteolytic enzymes. Some of the stored granules were utilized for strain isolation, and fluorescence in situ hybridization (FISH) tests.

\subsection{EPS extraction and characterization}

The EPSs from the original and stored granules were extracted following procedures utilized by Adav and Lee (2008). Briefly, the original granules (100 g, wet weight) were washed with Milli-Q water and then centrifuged at $5000 \mathrm{~g}$ for $15 \mathrm{~min}$ to recover the supernatant. The EPS in collected supernatant were named loosely bound EPSs (LB-EPSs). The residue was re-suspended to the original volume using a saline solution $(0.05 \% \mathrm{w} / \mathrm{w} \mathrm{NaCl})$ and extracted using the seven extraction methods described in Adav and Lee (2008). The extraction method used formaldehyde $+\mathrm{NaOH}$ as a chemical reagent, and applied ultrasound to enhance EPS extraction before or after extraction. The extracted fraction in the supernatant was the tightly bound EPS (TB-EPS), and the residual phase was pellets. That is, the quantities of TB-EPS and pellets were a product of adopted extraction methods. The extent of EPS contamination by intracellular materials was analyzed by measuring associated DNA content. For alkaline-treated samples, the extent of EPS contamination by cell lysis was estimated by measuring the quantity of 2-keto-3-deoxyoctonate (KDO) (Karkhanis et al., 1978). In all tests, the DNA and KDO contents in extracted EPS were low, suggesting minimal contamination by intracellular materials.

The amount of protein in extracted EPS was determined using the modified Lowry method (Frolund et al., 1995) with bovine serum albumin as the standard. The carbohydrate content in extracted EPS was measured using the Anthrone method with glucose as the standard. The DNA content was measured using the diphenylamine colorimetric technique (Sun et al., 1999) using fish DNA as the standard. Other sludge parameters, including total solids (TSs), volatile suspended solids (VSSs) and sludge volume index (SVI) were analyzed following standard methods (APHA, 1998).

\subsection{Enzyme assay}

Casein solution $(0.65 \%, 5 \mathrm{ml})$ prepared in $50 \mathrm{mM}$ potassium phosphate buffer was equilibrated at $37^{\circ} \mathrm{C}$. The enzyme reaction was initiated by adding $1 \mathrm{ml}$ of each enzyme solution into the sample solution, and a blank test without enzyme solution incubated for $10 \mathrm{~min}$ at $37^{\circ} \mathrm{C}$ while shaken. The reaction was stopped by adding $5 \mathrm{ml} 110 \mathrm{mM}$ trichloroacetic acid (TCA). After the reaction stopped, $1 \mathrm{ml}$ enzyme solution was added to the blank. Sample and blank solutions were filtered, and the filtrates were used for colorimetric tests to determine protein activity using the Lowry method (1951).

\subsection{EPS staining and fluorescence in situ hybridization (FISH)}

The collected stored granules were maintained fully hydrated during staining and FISH. Staining was conducted by adding calcofluor white (fluorescent brightener 28, Sigma, USA) solution (300 $\mathrm{mg} \mathrm{l}^{-1}, 100 \mu \mathrm{l}$ ) to sampled granules for $30 \mathrm{~min}$. The stained granules were washed twice with phosphate-buffered saline $(\mathrm{pH}$ 7.2) to remove excess stain. The granules were then prepared for FISH by fixing for $3 \mathrm{~h}$ in $4 \%$ paraformaldehyde. The fixed granules were embedded for cryosectioning in embedded medium (Shandon Cryomatrix, Pittsburgh, PA, USA). Embedded samples were frozen at $-20^{\circ} \mathrm{C}$. The $40-\mu \mathrm{m}$ sections were then cut on a cryomicrotome and mounted onto gelatin-coated $(0.1 \%$ gelatin and $0.01 \%$ chromium potassium sulfate) microscopic slides. The embedded compound was removed by washing with Milli-Q water and then hybridized for investigating the anaerobic strain Bacteroides sp. using hybridization buffer $(0.9 \mathrm{M} \mathrm{NaCl}, 20 \mathrm{mM}$ tris- $\mathrm{HCl}$ at $\mathrm{pH} 7.4,0.01 \%$ sodium dodecyl sulfate) containing $5 \mathrm{ng} \mathrm{ll}^{-1}$ of Bacto 1080 probe (5'-GCA CTT AAG CCG ACA CCT-3') (Tay et al., 2002b) labeled at the $5^{\prime}$-end with fluorescein phosphoramidite (FAM dye) for $2 \mathrm{~h}$ at $48^{\circ} \mathrm{C}$, and the hybridization solution contained $50 \%$ formamide. Parallel tests were conducted with granules hybridized with the same hybridization buffer as that mentioned above containing $5 \mathrm{ng} \mathrm{Hl}^{-1}$ of each ACA probe, complementary to a sequence helix 23a of Acinetobacter calcoaceticus (ATC CTC TCC CAT ACT CTA) (Wagner et al., 1994), and probe Pa03 Pseudomonas aeruginosa (GGA TCT TTG AAG TGA) (Keum et al., 2006). The stained and hybridized samples were examined by confocal laser scanning microscopy (CLSM) (Leica TCS SP5, Confocal Spectral Microscope Imaging System GmbH, Germany).

\subsection{Strain isolation and identification}

The stored phenol-fed granules were washed with Milli-Q water, and $1.0 \mathrm{~g}$ (wet weight) granules were placed aseptically in sterilized tubes, broken using a sterile glass rod and serially diluted with sterilized water to $10^{6}-10^{9}$ fold; $1 \mathrm{ml}$ of each $10^{6}-10^{9}$ dilution was plated into a plate with skimmed milk agar with the following composition: pancreatic digest of casein, $5 \mathrm{gl}^{-1}$; yeast extract, $2.5 \mathrm{~g} \mathrm{l}^{-1}$; glucose, $1 \mathrm{~g} \mathrm{l}^{-1}$; skim milk, $10 \mathrm{gl}^{-1}$; agar, $12 \mathrm{gl}^{-1}$; and, phenol, $0.25 \mathrm{~g} \mathrm{l}^{-1}$. The plates were incubated at $37^{\circ} \mathrm{C}$ in an incubator. Morphologically distinguished visible colonies showing halo zones were selected, picked up by sterile toothpicks and inserted onto other skim milk agar plates. Colonies were purified by several cycles of replating onto skim milk agar medium, and halo zones generated by colonies were determined. The DNA was extracted as described previously (Adav et al., 2007b) and the roughly fulllength 16S rDNA gene was amplified by PCR with forward primer 
F27 (5'-AGA GTT TGA TCM TGG CTC AG-3') and reverse primer R1492R (5'-TAC CTT GTT ACG ACT T-3'). The PCR products were purified using a PCR purification kit (Gene-Spin ${ }^{\mathrm{TM}}$, Protech Technology Enterprise, Ltd., Taiwan). The 16S rDNA gene sequence of the isolates was determined by using an ABI model 3730 DNA sequencer. The 16S rDNA sequences of the isolates were compared with 16S rDNA sequences obtained via BLAST searches of the national center for biotechnology information (NCBI) database (http:// www.nvbi.nlm.nih.gov). Multiple sequence alignments were performed using Clustal W version 1.8 and phylogenetic trees were constructed using the neighbor-joining method.

\section{Results}

\subsection{EPS contents and protease enzyme activities}

Fig. 1 lists the quantities of EPS extracted using ultrasoundformamide- $\mathrm{NaOH}$. The proteins extracted from granules were greater in quantity than carbohydrates. The protein content in seed sludge was $110 \pm 32 \mathrm{mg} \mathrm{g}^{-1} \mathrm{VSS}$, and increased to $457 \pm 54 \mathrm{mg} \mathrm{g}^{-1}$ VSS for granules cultivated for 35 or 50 days. Following storage for 60 days, protein content in the stored granules decreased to
$288 \pm 21 \mathrm{mg} \mathrm{g}^{-1}$ VSS (Fig. 1). The quantities of DNA and KDO in all extracted samples were $<0.3$ and $0.15 \mathrm{mg} \mathrm{g}^{-1} \mathrm{VSS}$, respectively, suggesting that the cell lysis effect was minimal during EPS extraction tests.

Table 1 lists the activities of protease enzymes in different fractions extracted from the original and stored granules using the nine extraction methods described (Adav et al., 2007a,b). Different extraction methods yield very different protease activities for a given fraction of granules, which is attributable to the fact that different extraction methods extract part of the EPS in granules. Enzyme activities in LB-EPS, TB-EPS and pellets were 0.45 ,

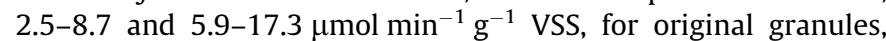
and $0.48,1.7-9.2$ and $5.2-21.1 \mu \mathrm{mol} \mathrm{min}^{-1} \mathrm{~g}^{-1}$ VSS, for stored granules, respectively. Protease activity was bound generally with TB-EPS and pellets of the aerobic granules. This observation correlates with findings by Yu et al. (2008) for wastewater sludge flocs.

\subsection{Proteolytic activity of isolates}

In total, 27 isolates were screened and selected from stored granules using skim milk agar. A clear halo was produced around

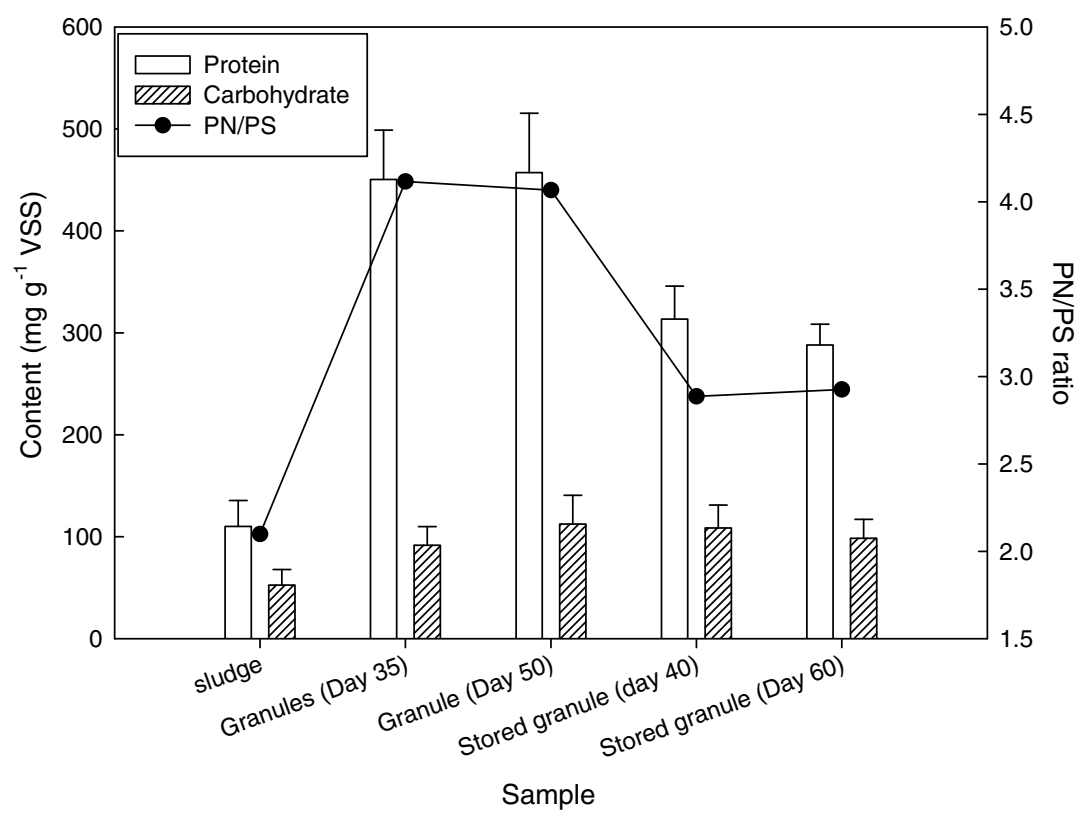

Fig. 1. Effect of total starvation and storage on EPS contents in aerobic granules.

Table 1

Protease activities in fractions extracted using different methods ${ }^{\mathrm{a}}$ units in $\mu \mathrm{mol} \mathrm{min} \mathrm{m}^{-1} \mathrm{~g}^{-1}$ VSS

\begin{tabular}{|c|c|c|c|c|c|c|c|c|}
\hline \multirow[t]{2}{*}{ Methods $^{\mathrm{b}}$} & \multicolumn{4}{|c|}{ Original granule } & \multicolumn{4}{|c|}{ Stored granule } \\
\hline & LB-EPS & TB-EPS & Pellet & Total & LB-EPS & TB-EPS & Pellet & Total \\
\hline Control & $0.45 \pm 0.02$ & $2.5 \pm 0.5$ & $6.6 \pm 0.5$ & $9.5 \pm 5.3$ & $0.48 \pm 0.01$ & $1.7 \pm 0.3$ & $5.2 \pm 0.3$ & $7.5 \pm 3.3$ \\
\hline Ultrasound & & $6.9 \pm 1.1$ & $12.3 \pm 1.3$ & $18.6 \pm 4.2$ & & $7.2 \pm 0.9$ & $14.8 \pm 1.1$ & $22.6 \pm 4.2^{*}$ \\
\hline EDTA & & $5.3 \pm 0.5$ & $9.5 \pm 2.3$ & $15.2 \pm 3.3$ & & $3.1 \pm 0.3$ & $8.5 \pm 1.9$ & $12.2 \pm 3.3$ \\
\hline Formaldehyde & & $6.0 \pm 2.0$ & $14.3 \pm 1.6$ & $22.6 \pm 7.9$ & & $6.8 \pm 1.3$ & $16.2 \pm 0.9$ & $24.1 \pm 7.9$ \\
\hline Formaldehyde $+\mathrm{NaOH}$ & & $3.2 \pm 0.3$ & $7.1 \pm 3.0$ & $11.7 \pm 3.8$ & & $2.2 \pm 0.5$ & $8.1 \pm 2.2$ & $11.7 \pm 2.8$ \\
\hline Ultrasound + formaldehyde $+\mathrm{NaOH}$ & & $3.5 \pm 1.1$ & $9.8 \pm 9.6$ & $13.9 \pm 4.3$ & & $3.7 \pm 0.8$ & $9.9 \pm 2.6$ & $14.5 \pm 3.3$ \\
\hline Foarmaldehyde $+\mathrm{NaOH}+$ ultrasound & & $5.2 \pm 2.4$ & $5.9 \pm 7.9$ & $11.5 \pm 4.1$ & & $6.2 \pm 1.7$ & $6.2 \pm 2.9$ & $12.5 \pm 3.1$ \\
\hline Formamide & & $8.7 \pm 1.8$ & $17.3 \pm 5.3$ & $26.4 \pm 4.8$ & & $9.2 \pm 1.1$ & $21.1 \pm 4.3$ & $30.4 \pm 4.8^{* *}$ \\
\hline Ultrasound + formamide $+\mathrm{NaOH}$ & & $5.2 \pm 2.2$ & $7.6 \pm 4.6$ & $12.2 \pm 3.3$ & & $6.2 \pm 1.8$ & $7.9 \pm 2.4$ & $14.2 \pm 3.3$ \\
\hline Formamide $+\mathrm{NaOH}+$ ultrasound & & $2.9 \pm 0.2$ & $9.8 \pm 7.0$ & $12.9 \pm 4.3$ & & $3.2 \pm 0.7$ & $9.9 \pm 7.0$ & $13.9 \pm 4.3$ \\
\hline
\end{tabular}

\footnotetext{
a EPS extracted following methods in Adav et al. (2007a).
}

b $* p<0.05, * * p<0.01 v s$. corresponding total values of mature granule (Tukey-Kramer multiple comparisons test). 
the proteolytic colony (image not shown). A parameter, relative halo size, was determined as follows:

Relative halo size $=\frac{D_{\text {halo }}-D_{\text {colony }}}{D_{\text {colony }}} \times 100$

where $D_{\text {halo }}$ is the diameter of the halo formed around the colony $(\mathrm{mm})$, and $D_{\text {colony }}$ is the colony diameter $(\mathrm{mm})$. As relative halo size increases, the proteolytic activity yielded by colony unit volume increases. Fig. 2 presents the proteolytic activities of isolates in terms of the relative halo size obtained in skim milk agar. Isolates PB1, PB11 and PB28 had significantly higher ( $p<0.01$, ANOVA) proteolytic activities than the other isolates.

\subsection{Phylogenetic analysis of $16 S$ rDNA sequences of isolates}

The 27 screened isolates were utilized for subsequent 16S rDNA sequencing and phylogenetic analysis (Table 2). Phylogenetic analysis of 16S rDNA sequences demonstrates that the isolates were members of three principal groups: Proteobacteria, Enterobacteriaceae and Firmicute. The most abundant isolates were Proteobacteria (70\%), particularly of the Pseudomonas genus. Nineteen isolates were associated with different genera in the lineage of gammaproteobacteriaceae, namely, P. aeruginosa, Pseudomonas grimontii, Pseudomonas fragi, Pseudomonas aurantiaca and Pseudomonas mediterranea with 97-99\% sequence similarity. Three isolates

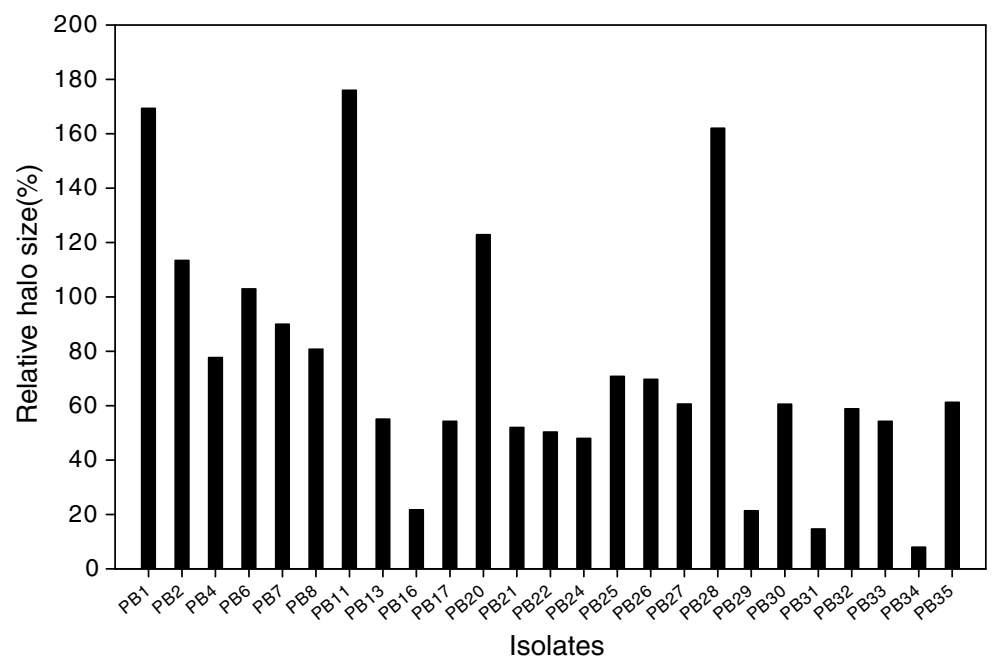

Fig. 2. Proteolytic activity of the isolates in terms of halo zones.

Table 2

Taxonomic affiliations of the proteolytic isolates from stored granule and closely related microbial strain

\begin{tabular}{|c|c|c|c|c|c|c|}
\hline $\begin{array}{l}\text { Isolate } \\
\text { name }\end{array}$ & $\begin{array}{l}\text { 16S rDNA base pairs } \\
\text { used for identity }\end{array}$ & $\begin{array}{l}\text { GenBank accession } \\
\text { number }\end{array}$ & Closely related microbial strain & $\begin{array}{l}\text { Ref. strain } \\
\text { accession No }\end{array}$ & $\begin{array}{l}\text { Identity } \\
(\%)\end{array}$ & Taxonomic affiliation \\
\hline PB1 & 1163 & EU360101 & P. aeruginosa strain 8 & EF362637 & 97 & Gammaproteobacteria \\
\hline PB2 & 1149 & EU360102 & P. grimontii strain B5 & EU169177 & 97 & Gammaproteobacteria \\
\hline PB4 & 1144 & EU360103 & Uncultured gamma proteobacterium clone S-H52 & AY622270 & 97 & Gammaproteobacteria \\
\hline PB6 & 1156 & EU360104 & Pseudomonas sp. BWDY-24 & DQ219370 & 97 & Gammaproteobacteria \\
\hline PB7 & 1137 & EU360105 & P. fragi & AY195842 & 98 & Gammaproteobacteria \\
\hline PB8 & 1125 & EU360106 & Pseudomonas syringae pv. coryli strain NCPPB 4273 & AJ889841 & 98 & Gammaproteobacteria \\
\hline PB11 & 1278 & EU360107 & P. aeruginosa PA7 & СР000744 & 99 & Gammaproteobacteria \\
\hline PB13 & 1332 & EU360108 & Uncultured bacterium clone P1D1 & EF511972 & 99 & Gammaproteobacteria \\
\hline PB14 & 1392 & EU360109 & Uncultured bacterium clone P1D1-553 & EF511914 & 100 & Gammaproteobacteria \\
\hline PB15 & 1365 & EU360110 & Raoultella planticola strain Rs-2 & EF551363 & 99 & Enterobacteriaceae \\
\hline PB16 & 1408 & EU360111 & A. calcoaceticus strain $\mathrm{TS} 2 \mathrm{H}$ & EF151807 & 99 & Gammaproteobacteria \\
\hline PB17 & 1413 & EU360112 & P. agglomerans strain MY1 & AJ506794 & 99 & Enterobacteriaceae \\
\hline PB20 & 1179 & EU360113 & Acinetobacter genomo sp. 3 strain Ab297 & EF672506 & 95 & Gammaproteobacteria \\
\hline PB21 & 1374 & EU360114 & Uncultured bacterium clone P5D23-430 & EF511828 & 95 & Gammaproteobacteria \\
\hline PB22 & 1203 & EU360115 & Pandoraea sp. S14 & AY741155 & 95 & Enterobacteriaceae \\
\hline PB24 & 1411 & EU360116 & Klebsiella pneumoniae & СР000647 & 99 & Enterobacteriaceae \\
\hline PB25 & 1407 & EU360117 & Pseudomonas sp. HF4-5 & DQ288110 & 100 & Gammaproteobacteria \\
\hline PB26 & 1174 & EU360118 & P. aurantiaca strain B23 & EU169169 & 97 & Gammaproteobacteria \\
\hline PB27 & 1276 & EU360119 & Lysinibacillus sphaericus stain NBRC 3525 & AB363739 & 99 & Firmicutes \\
\hline PB28 & 1247 & EU360120 & B. sphaericus & AB271742 & 97 & Firmicutes \\
\hline PB29 & 1411 & EU360121 & Enterobacteriaceae bacterium NR58 & DQ520801 & 99 & Enterobacteriaceae \\
\hline PB30 & 1297 & EU360122 & Bacillus cereus strain $\mathrm{Z7}$ & EU236738 & 99 & Firmicutes \\
\hline PB31 & 1401 & EU360123 & Klebsiella sp. A18-1 & AB244431 & 99 & Enterobacteriaceae \\
\hline PB32 & 1200 & EU360124 & Acinetobacter sp. MUB1 & AY273199 & 95 & Gammaproteobacteria \\
\hline PB33 & 1185 & EU360125 & P. mediterranea G-229- & EF673038 & 97 & Gammaproteobacteria \\
\hline PB34 & 1374 & EU360126 & Uncultured bacterium clone P1D1-562 & EF511995 & 99 & Gammaproteobacteria \\
\hline PB35 & 1181 & EU360127 & Acinetobacter baumannii strain KSC_tot4-a & DQ870679 & 95 & Gammaproteobacteria \\
\hline
\end{tabular}




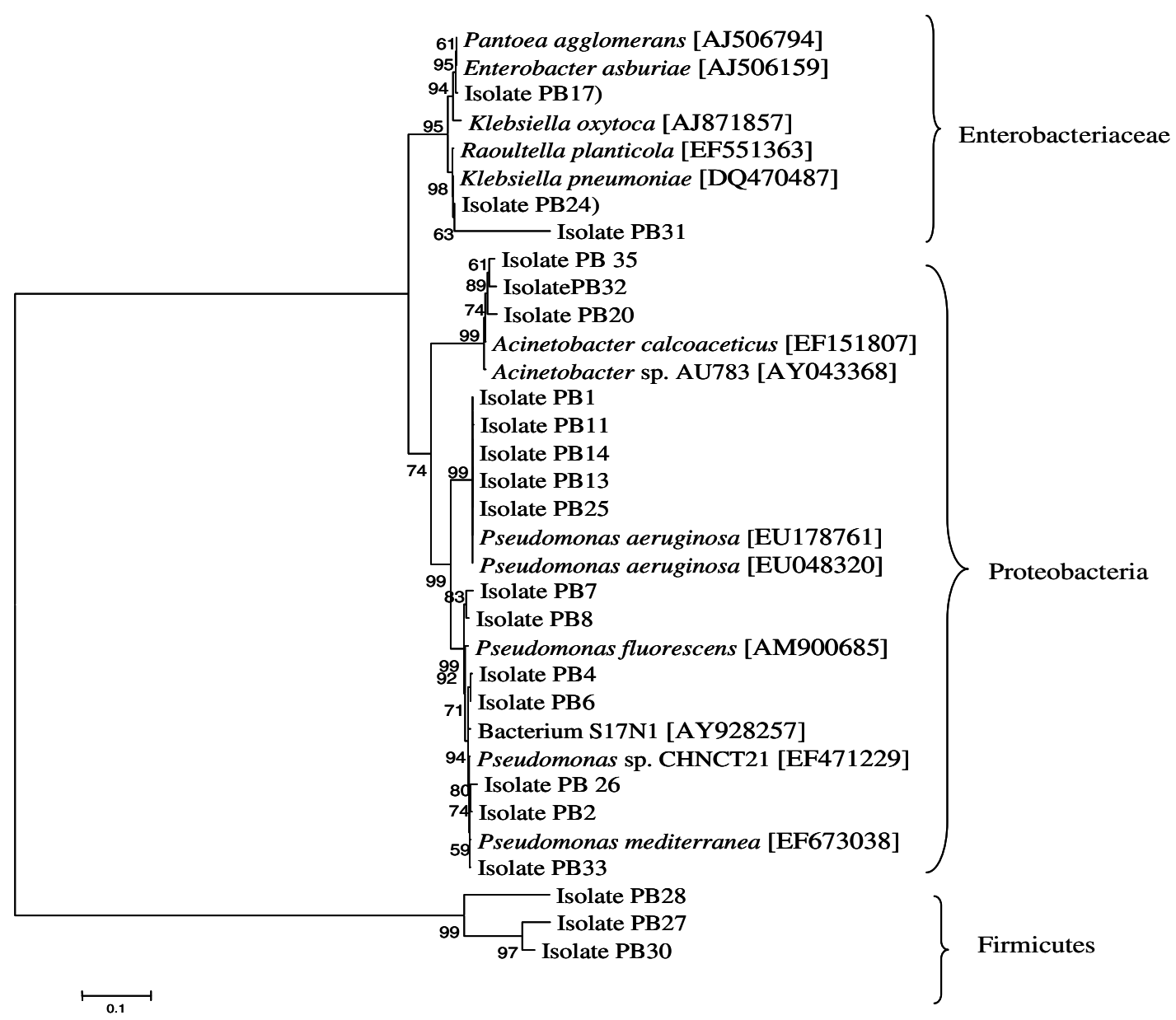

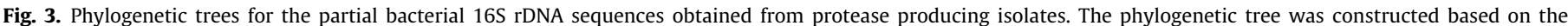

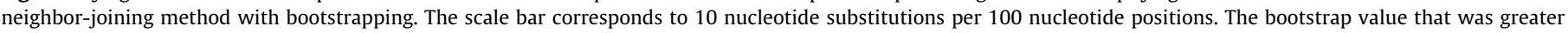
than $50 \%$ was shown at each node.

were members of Firmicute and five were associated with Enterobacteriaceae.

Isolates PB1, PB11, PB13, PB14 and PB25 formed subclusters supported by $99 \%$ bootstrap confidence values, whereas isolates PB7, PB8, PB4, PB6, PB26 and PB2 formed separate subclusters in Proteobacteria with a bootstrap confidence limit of 71-99\% (Fig. 3). Isolates PB35, PB32, and PB20 belonged to the genus Acinetobacter. Isolate PB17 was associated with Pantoea agglomerans with a 61\% bootstrap confidence index and Enterobacter asburiae (95\%, bootstrap) was under the Entrobacteriaceae.

\section{Discussion}

\subsection{Protein hydrolysis and protease enzyme activities}

Total protein contents in stored granules (Fig. 1) were significantly lower than those in original granules $(p<0.001$, ANOVA). Conversely, polysaccharide contents in original granules were close to those in stored granules (60 days). That is, granule storage significantly reduced protein content, and had no significant effect on polysaccharide content.

The total activities of protease follow formamide $>$ formaldehyde $>$ ultrasoinication $>$ EDTA $>$ ultrasound-formaldehyde- $\mathrm{NaOH}>$ formamide- $\mathrm{NaOH}$-ultrasound $>$ ultrasound-foamamide- $\mathrm{NaOH}>$ formaldehyde- $\mathrm{NaOH}>$ formaldehyde- $\mathrm{NaOH}$-ultrasound $>$ control. Enzymes extracted by ultrasound and formamide from stored gran- ules had higher protease enzyme compared with corresponding total enzyme content in original granules. The high protease activities of original granules correspond to hydrolysis of the $400 \mathrm{mg} \mathrm{l}^{-1}$ peptone in replenished influent wastewater. Conversely, the high protease activity of stored granules likely corresponds to hydrolysis of extracellular proteins as the amount of proteins in storage medium was limited. This experimental observation correlates with the reduction in protein contents for granules following storage (Fig. 1).

\subsection{Proteolytic bacteria in stored granules}

Isolates PB1 (P. aeruginosa strain 8), PB11 (P. aeruginosa PA7) and PB28 (Bacillus sphaericus) had significantly high proteolytic activity during the skim milk agar test. Furthermore, FISH-CLSM imaging indicated that proteolytic bacteria were distributed over the core regime of stored granules (image not shown). In other words, the proteolytic bacteria were present in stored granules, and were located at the core regime of high protease activities.

The FISH-CLSM image of the obligate anaerobic strain Bacteroides sp. was shown to primarily locate $200-300 \mu \mathrm{m}$ beneath the granule surface. That is, the proteolytic strain $P$. aeruginosa was primarily located close to the anaerobic Bacteroides sp.

Hence, this study for the first time isolates and identifies proteolytic bacteria from stored aerobic granules, and demonstrates the close relationship between spatial distributions of proteolytic bacteria and the activity of protease enzymes. Additionally, this work 
demonstrates that the identified proteolytic strain was located close to the obligate anaerobic strain Bacteroides sp. inside the granule. Hence, this study supports the hypothesis of Adav et al. (2007a) that anaerobic degradation of extracellular proteins in granule cores corresponds to stability loss of stored granules. Extracellular proteins were hydrolyzed by enzymes secreted by proteolytic bacteria, such as $P$. aeruginosa, and the hydrolyzed products were utilized by nearby anaerobic strains. This "partnership" gradually digests the granules from the inside out, eventually resulting in granule breakdown. With the likely inhibition effects of phenol on proteolytic bacteria, Adav et al. (2007a) successfully stored their granules in phenol-containing medium for over 180 days without severe loss of structural stability.

\section{Conclusion}

The mechanisms corresponding to loss of granule stability during storage were studied. During 60 days storage, the extracellular proteins were noted significantly decreased $457 \pm 54 \mathrm{mg} \mathrm{g}^{-1}$ VSS to $288 \pm 21 \mathrm{mg} \mathrm{g}^{-1}$. Meanwhile, the enzyme activities in LB-EPS, TBEPS and pellets were high: $0.45,2.5-8.7$ and $5.9-17.3 \mu \mathrm{mol} \mathrm{min}$ ${ }^{-1} \mathrm{~g}^{-1}$ VSS for original granules, and $0.48,1.7-9.2$ and $5.2-$ $21.1 \mu \mathrm{mol} \mathrm{min}{ }^{-1} \mathrm{~g}^{-1}$ VSS for stored granules. The proteolytic bacteria that respond to protein hydrolysis inside stored granules were isolated and identified for the first time. Particularly, the proteolytic PB1 ( $P$. aeruginosa) strain was distributed at the core regime, close to the obligate anaerobic strain Bacteroides sp. This work hypothesized that the protease enzyme secreted by proteolytic bacteria hydrolyzed the extracellular proteins in the stored granules, which was then the used by the nearby anaerobic strains. The protein core gradually deteriorated by this combined process.

\section{References}

Adav, S.S., Chen, M.Y., Lee, D.J., Ren, N.Q., 2007a. Degradation of phenol by aerobic granules and isolated yeast Candida tropicalis. Biotechnol. Bioeng 96, 844-852.

Adav, S.S., Lee, D.J. 2008. Extraction of extracellular polymeric substances from aerobic granule with compact interior structure. J. Haz. Mat. doi:10.1016 j.jhazmat.2007.11.058.

Adav, S.S., Lee, D.J., Tay, J.H., 2007b. Activity and structure of stored aerobic granules. Environ. Technol. 28, 1227-1235.

APHA, 1998. Standard Methods for the Examination of Water and Wastewater, 20th ed. American Public Health Association, Washington, DC.

Beun, J.J., Hendriks, A., van Loosdrecht, M.C.M., Morgenroth, E., Wilderer, P.A Heijnen, J.J., 1999. Aerobic granulation in a sequencing batch reactor. Water Res. 33, 2283-2290.

Boyd, A., Chakrabarty, A.M., 1994. Role of alginate lyase in cell detachment of Pseudomonas aeruginosa. Appl. Environ. Microbiol. 60, 2355-2359.

Cadoret, A., Conrad, A., Block, J.C., 2002. Availability of low and high molecular weight substrates to extracellular enzymes in whole and dispersed activated sludges. Enzyme Microb. Technol. 31, 179-186.

Frolund, B., Keiding, K., Nielsen, P.H., 1995. Enzymatic activity in the activated sludge flocs matrix. Appl. Microbiol. Biotechnol. 43, 755-761.

Karkhanis, A.D., Zeltner, J.Y., Carlo, D.J.C., 1978. A new and improved microassay to determine 2-keto-3-deoxyoctonate in lipopolysaccharide of Gram-negative bacteria. Anal. Biochem. 85, 595-601.

Keum, K.C., Yoo, S.M., Lee, S.Y., Chang, K.H., Yoo, N.C., Yoo, W.M., Kim, J.M., Choi, J.Y., Kim, J.S., Lee, G., 2006. DNA microarray-based detection of nosocomia pathogenic Pseudomonas aeruginosa and Acinetobacter baumannii. Mol. Cell Probe 20, 42-50.
Liu, Q.S., Liu, Y., Tay, S.T.L., Show, K.Y., Ivanov, V., Benjamin, M., Tay, J.H., 2005. Startup of pilot-scale aerobic granular sludge reactor by stored granules. Environ. Technol. 26, 1363-1369.

Liu, Q.Y., Liu, Y., Tay, J.H., 2004b. The effects of extracellular polymeric substances on the formation and stability of biogranules. Appl. Microbiol. Biotechnol. 65, 143-148.

Liu, Y., Liu, Q.S., Qin, L., Tay, J.H., 2004a. Comments on “effect of extended idle conditions on structure and activity of granular activated sludge" by Zhu and Wilderer. Water Res. 38, 3465-3466.

Liu, Y.Q., Tay, J.H., 2008. Influence of starvation time on formation and stability of aerobic granules in sequencing batch reactors. Bioresour. Technol. 99, 980-985.

Lowry, O.H., Rosebrough, N.J., Farn, A., Randall, R., 1951. Protein measurement with the folin phenol reagent. J. Biol. Chem. 193, 265-275.

Ni, B.J., Yu, H.Q., 2008. Storage and growth of denitrifiers in aerobic granules: Part I. Model dev. Biotechnol. Bioeng. 99, 314-323.

Ni, B.J., Yu, H.Q., Xie, W.M., 2008. Storage and growth of denitrifiers in aerobic granules: Part II. Model calibration and verification. Biotechnol. Bioeng. 99, 324-332.

Nielsen, P.H., Frolund, B., Keiding, K., 1996. Changes in the composition of extracellular polymeric substances in activated sludge during anaerobic storage. Appl. Microbiol. Biotechnol. 44, 823-830.

Patel, J.J., Gerson, T., 1974. Formation and utilization of carbon reserves by Rhizobium. Arch. Microbiol. 101, 211-220.

Peng, D.C., Bernet, N., Delgenes, J.P., Moletta, R., 1999. Aerobic granular sludge - A case report. Water Res. 33, 890-893.

Ruijssenaars, H.J., Stingele, F., Hartmans, S., 2000. Biodegradability of foodassociated extracellular polysaccharides. Curr. Microbiol. 40, 194-199.

Su, K.Z., Yu, H.Q., 2005. Formation and characterization of aerobic granules in a sequencing batch reactor treating soybean-processing wastewater. Environ. Sci. Technol. 39, 2818-2828.

Sun, Y., Clinkenbeard, K.D., Clarke, C., Cudd, L., Highlander, S.K., Dabo, S.M., 1999. Pasteurella haemolyticaleukotoxin induced apoptosis of bovine lymphocytes involves DNA fragmentation. Vet. Microbiol. 65, 153-166.

Tay, J.H., Liu, Q.S., Liu, Y., 2001a. The effects of shear force on the formation, structure and metabolism of aerobic granules. Appl. Microbiol. Biotechnol. 57, 227-233.

Tay, J.H., Liu, Q.S., Liu, Y., 2001b. The role of cellular polysaccharides in the formation and stability of aerobic granules. Lett. Appl. Microbiol. 33, 222-226.

Tay, J.H., Liu, Q.S., Liu, Y., 2002a. Characteristics of aerobic granules grown on glucose and acetate in sequential aerobic sludge blanket reactors. Environ. Technol. 23, 931-936.

Tay, S.T.L., Ivanov, V., Yi, S., Zhuang, W.Q., Tay, J.H., 2002b. Presence of anaerobic Bacteroides in aerobically grown microbial granules. Microbiol. Ecol. 44, 278285.

Wagner, M., Erhart, R., Manz, W., Amann, R., Lemmer, H., Wedi, D., Schleifer, K.H., 1994. Development of an rRNA-targeted oligonucleotiode probe specific for the genus Acinetobacter and its application for in situ monitoring in activated sludge. Appl. Environ. Microbiol. 60, 792-800.

Wang, S.G., Liu, X.W., Gong, W.X., Gao, B.Y., Zhang, D.H., Yu, H.Q., 2007. Aerobic granulation with brewery wastewater in a sequencing batch reactor. Bioresource. Technol. 98, 2142-2147.

Wang, Z.W., Li, Y., Zhou, J.Q., Liu, Y., 2006. The influence of short-term starvation on aerobic granules. Process Biochem. 41, 2373-2378.

Yang, S.F., Liu, Q.S., Tay, J.H., Liu, Y., 2004. Growth kinetics of aerobic granules developed in sequencing batch reactors. Lett. Appl. Microbiol. 38, 106-112.

Yu, G.H., He, P.J., Shao, L.M., Lee, D.J., 2008. Enzyme activities in activated sludge flocs. Appl. Microbiol. Biotechnol. doi:10.1007/s00253-007-1204-5.

Zeng, P., Zhuang, W.Q., Tay, S.T.L., Tay, J.H., 2007. The influence of storage on the morphology and physiology of phthalic acid-degrading aerobic granules. Chemosphere 69, 1751-1757.

Zhang, L.L., Feng, X.X., Zhu, N.W., Chen, J.M., 2007. Role of extracellular protein in the formation and stability of aerobic granules. Enzyme Microb. Technol. 41, 551-557.

Zhang, L.L., Zhang, B., Huang, Y.F., Cai, W.M., 2005. Re-activation characteristics of preserved aerobic granular sludge. J. Environ. Sci. 17, 655-658.

Zhang, X.Q., Bishop, P.L., 2003. Biodegradability of biofilm extracellular polymeric substances. Chemosphere 50, 63-69.

Zhang, X.Q., Bishop, P.L., Kinkle, B.K., 1999. Comparison of extraction methods for quantifying extracellular polymers in biofilms. Water Sci. Technol. 39, 211-218. Zhu, J., 2004. Reply to comment by J. Zhu. Water Res. 38, 3467-3469.

Zhu, J., Wilderer, P.A., 2003. Effect of extended idle conditions on structure and activity of granular activated sludge. Water Res. 37, 2013-2018. 